\title{
Molecular analysis and genotype-phenotype correlations in patients with classical congenital adrenal hyperplasia due to 21-hydroxylase deficiency from southern Poland - experience of a clinical center
}

\author{
Anna Kurzyńska ${ }^{1} \cdot$ Anna Skalniak $^{1} \cdot \mathrm{Kim}_{\mathrm{Franson}}{ }^{2} \cdot$ Viola Bistika $^{3} \cdot$ Alicja Hubalewska-Dydejczyk $^{1}$. \\ Elwira Przybylik-Mazurek ${ }^{1}$ (1)
}

Received: 12 March 2021 / Accepted: 30 December 2021 / Published online: 26 January 2022

(c) The Author(s) 2022

\begin{abstract}
Purpose The prevalence of CYP21A2 gene variants and genotype-phenotype correlations are variable among populations. The aim of this study was to characterize CYP21A2 gene variants in adult patients with classical congenital adrenal hyperplasia $(\mathrm{CCAH})$ from southern Poland and to analyze genotype-phenotype correlations.

Materials/Methods A total of 48 patients (30 women and $18 \mathrm{men}$ ) with CCAH were included in the study. Patients were divided into two clinical subgroups, namely, salt-wasting (SW) - 38 patients and simple virilizing (SV) - 10 patients. A genetic analysis MLPA (multiplex ligation-dependent probe amplification) was performed in all of them. In dubious cases, the analysis was complemented by Sanger sequencing. Genotypes were classified into five groups (depending on the residual in vitro enzymatic activity), namely, null, A, B, C, and D, and correlated with the clinical picture.

Results Molecular defects were investigated and identified in 48 patients. The most common variant in the studied group was I2G, followed by whole or partial gene copy deletion, and I172N. One novel variant c.[878G $>$ T] (p.Gly293Val) was found. In nine patients, a non-concordance between genotype and phenotype was observed. Genotype-phenotype correlations measured by positive predictive value (PPV) were as follows: $100 \%$ in group null, $90.5 \%$ in group A, and $66.7 \%$ in group B. Conclusions CYP21A2 variants in the studied cohort were similar to values previously reported in other countries of the region. There was a good correlation between genotype and phenotype in the null and A groups, the correlation being considerably lower in group B.
\end{abstract}

Keywords Congenital adrenal hyperplasia $\cdot C Y P 21 A 2 \cdot$ Genotype-phenotype correlation $\cdot 21$-hydroxylase deficiency

\section{Introduction}

Congenital adrenal hyperplasia $(\mathrm{CAH})$ is an endocrine disorder caused by mutations of genes coding for the synthesis of enzymes involved in adrenal steroidogenesis. Based on the type of enzyme block, several CAH types can be distinguished. The most common type (which accounts for about $95-99 \%$ of cases) is related to mutation in the CYP21A2 gene, encoding 21-hydroxylase, and may result

Elwira Przybylik-Mazurek

elwira.przybylik-mazurek@uj.edu.pl

1 Clinical Department of Endocrinology, Jagiellonian University Medical College, Krakow, Poland

2 Karolinska Institute, Stockholm, Sweden

3 Faculty of Medicine, Hacettepe University, Ankara, Turkey in different clinical forms, namely, classical, including saltwasting (SW) and simple virilizing (SV), and nonclassical (NCCAH), the latter manifesting at a later age and characterized by milder symptoms [1-3]. The incidence of $\mathrm{CAH}$ is estimated at about 1:15,000 and differs among populations [4]. In some ethnic groups, the reported prevalence is higher (for example, in the population of La Réunion, it is 1:2141 [5], and among Yupik Eskimos, it is 1:280 [6]). In the Caucasian population, the prevalence of the disease varies from 1 in 5000 to 1 in 23,000 live births [7]. According to the latest data, in the USA, the incidence of CAH varies from 1:9941 to 1:28,661 live births [8]. The CYP21A2 gene is located on the short arm of chromosome 6 (6p21.3) [9]. The inactive pseudogene, CYP21A1P, is $98 \%$ homologous compared to the active form of CYP21A2 and contains variants which, when incorporated in the active gene, can lead to the loss of its functions. The majority of pathogenic variants 
(about 90-95\%) occurring within CYP21A2 originate from this pseudogene. Within the active gene, there are also de novo variants causing only a small portion of inherited cases of CAH [10]. Different variants in the CYP21A2 gene can lead to a variable degree of loss of 21-hydroxylase activity, which can result in various clinical presentations. To date, over 200 variants with a pathogenic role have been described $[11,12]$. The majority of pathogenic variants in the CYP21A2 gene are large conversions, large deletions, or one of nine small variants, as follows: p.Gly111Valfs*21 (classically designated as "del8bp" or " $\Delta 8 \mathrm{bp}$ "), exon 6 ("E6") cluster (p.[Ile237Asn; Val238Glu; Met240Lys]), p.Leu308Phefs*6 (“F306+T”), p.Gln319Ter (“Q318X”), p.Arg357Trp (“R356W"), p.Ile173Asn (“I172N"), p.Pro31Leu, p.Val282Leu, p.Pro454Ser, and c.293-13A/ C $>$ G ("I2G") [13]. Molecular defects in Polish patients with $\mathrm{CAH}$ have not so far been analyzed. Therefore, the aim of our study was to identify the spectrum of variants in adult patients from southern Poland with classical congenital adrenal hyperplasia (CCAH) due to 21-hydroxylase deficiency and to analyze genotype-phenotype correlations.

\section{Materials and methods}

\section{Study population}

Forty-eight adult patients diagnosed with CCAH due to 21-hydroxylase deficiency, treated at the Department of Endocrinology, University Hospital Medical College, Krakow, Poland, between 2015 and 2019 were enrolled in this study. In the study group, there were 30 women aged 28.20 $( \pm 12.12)$ years and 18 men aged $27.70( \pm 8.97)$ years. In total, 38 patients (79.17\%) had the SW form and 10 (20.83\%) the SV form. The CCAH diagnosis was made based on the clinical and physical examination and retrospective analysis of the patients' medical history. Data such as age at onset of the disease, electrolyte disturbances, genital appearance, previous urological surgery, evidence of hyperandrogenism, hormonal data including 17-hydroxyprogesterone (17-OHP), ACTH, plasma renin activity (PRA), aldosterone levels, and treatment scheme were taken into consideration. Patients who presented symptoms of adrenal crisis as neonates were classified in the SW group. Patients diagnosed in early childhood, but without salt-wasting form symptoms, were assigned to the SV group.

This study is in compliance with the 1964 Declaration of Helsinki and its later amendments. All patients signed an informed consent for participation in the study; an additional informed consent for the genetic analysis was also obtained. The study was approved by the Ethics Committee of the Jagiellonian University Medical College: KBET/225/B/2013.

\section{Statistical analysis}

Continuous data with normal distribution are presented as mean value and standard deviation (SD), and non-normal variables are reported as median and interquartile range (IQR) (Me [Q1;Q3]). Categorical data are presented as percentages. Due to the small size of the groups, continuous data were compared using the Kruskal-Wallis test. Categorical data were compared using the chi-square test. A $P$-value below 0.05 was considered statistically significant. To obtain a visual representation of global patterns within the data, correspondence analysis was implemented. Data were analyzed using Statistica 13.0.

\section{Molecular analysis}

DNA was extracted from peripheral blood samples using the NucleoSpin Blood kit (Macherey-Nagel Inc.), according to the manufacturer's protocol. Genetic analysis based on MLPA (multiplex ligation-dependent probe amplification), with the use of the probemix SALSA MLPA P050 CAH from MRC Holland, was performed according to the manufacturer's recommendations, using $50 \mathrm{ng}$ of the isolated DNA per sample. The SALSA MLPA Probemix from MRC Holland, which enables detection of large rearrangements and seven of the most common point mutations in one reaction mix at the same time, was used as the first step of molecular testing of our studied group. In dubious cases, it was complemented by Sanger sequencing, based on the method published by Xu et al. [14]. For the long-range PCR reaction, Amplus polymerase (EurX Sp. $\mathrm{z}$ o.o.) was used according to the manufacturer's recommendations, with $200 \mathrm{ng}$ DNA per $25 \mu \mathrm{l}$ reaction volume and betaine (Sigma-Aldrich) added to the reaction mixture at a final concentration of $1 \mathrm{M}$. The reaction was performed on an Eppendorf Mastercycler realplex thermocycler with an annealing temperature of $61^{\circ} \mathrm{C}$ and $20 \mathrm{sec}$ added to each elongation step beginning from cycle 21 . After agarose gel verification, the remaining reaction mixture was purified with NucleoSpin PCR Clean-up (Macherey-Nagel). The sequencing PCR reaction was performed with BigDye Terminator v3.1 (ThermoFisher Applied Biosystems) and $120 \mathrm{ng}$ of the purified PCR product in $10 \mu \mathrm{l}$ reaction volume. The sequencing conditions were in accordance with the manufacturer's recommendations, with an annealing temperature of $55^{\circ} \mathrm{C}$. Products were purified by ethanol precipitation, and pellets were resuspended in 20 $\mu 1$ nuclease-free water for capillary electrophoresis (ABI 3500, Applied Biosystems).

Four patients were excluded from further analysis because it was not possible to determine the distribution 
of variants on individual alleles without performing molecular analysis of the patients' parents, who were not available for testing. Genotypes were categorized into five groups (according to the published residual in vitro activity of 21-hydroxylase, based on literature data [15, 16]), namely, groups null, A, B, C, and D, and then compared with the clinical presentation (excepting group $\mathrm{C}$, which was excluded from further analyses). Group null, with $0 \%$ residual enzyme function, included patients with alterations found in both alleles of CYP21A2, causing a total absence of enzymatic activity (deletions, gene conversions, F306+T, del8bp, cluster E6, R356W, and Q318X). Group A (0-1\% residual 21-hydroxylase activity) comprised patients who were I2G homozygotes or heterozygotes consisting of $\mathrm{I} 2 \mathrm{G}$ and another variant, with minimal enzymatic activity $(0-1 \%)$. Homozygotic patients with the variant I172N (approximately 2\% of residual 21-hydroxylase enzyme activity) or heterozygotes with the null, A, or B group variants were assigned to group B, with 1-2\% residual enzyme activity. Genotype group $C$ (patients with moderately impaired 21-hydroxylase activity and with about $20-60 \%$ preserved residual enzymatic function) were homozygotes or heterozygotes of the milder variants. Patients who were carriers of variants of unknown in vitro impact on residual enzymatic activity were assigned to genotype group D. The global representation of these classes with different $C Y P 21 A 2$ variants is depicted in Fig. 1. The presented variants are numbered according to reference sequences NM_000500.9 (at DNA level) and NP_000491.4 (at protein level). Additionally, common genetic variants are referred to in accordance with classically used designations to maintain coherence with other literature sources.

\section{Results}

Among the group of 44 patients with CCAH (88 alleles), CYP21A2 gene mutations were detected in all of them. A total of $100 \%$ of the analyzed 88 alleles revealed a mutation of the CYP21A2 gene. The CYP21A2 gene variants found in our study group are shown in Fig. 2.

The most common alteration in CCAH patients was the $\mathrm{I} 2 \mathrm{G}$ (c.293-13A/C $>\mathrm{G}$ ) variant with an allele frequency of $38.63 \%$, followed by large deletions and I172N (p.Ile173Asn) (32.95\% and $12.5 \%$ of all alleles, respectively). Other detected variants, from the most to the least prevalent, were as follows: p.Val282Leu, SNP-113 (c.113G>A), Q318X (p.Gln319Ter), R356Q (p.Arg357Gln), R356W (p.Arg357Trp), p.Trp20Ter, p.Pro31Leu, del8bp (p.Gly111Valfs*21), F306+T (p.Leu308Phefs*6), and c. $738+12 \_738+13$ delACinsGT.

Genetic variant distribution among the 88 alleles according to genotype groups null, A, B, and D is presented in Table 1.
Fig. 1 CYP21A2 variants found in 44 patients (88 alleles) with $\mathrm{CCAH}$

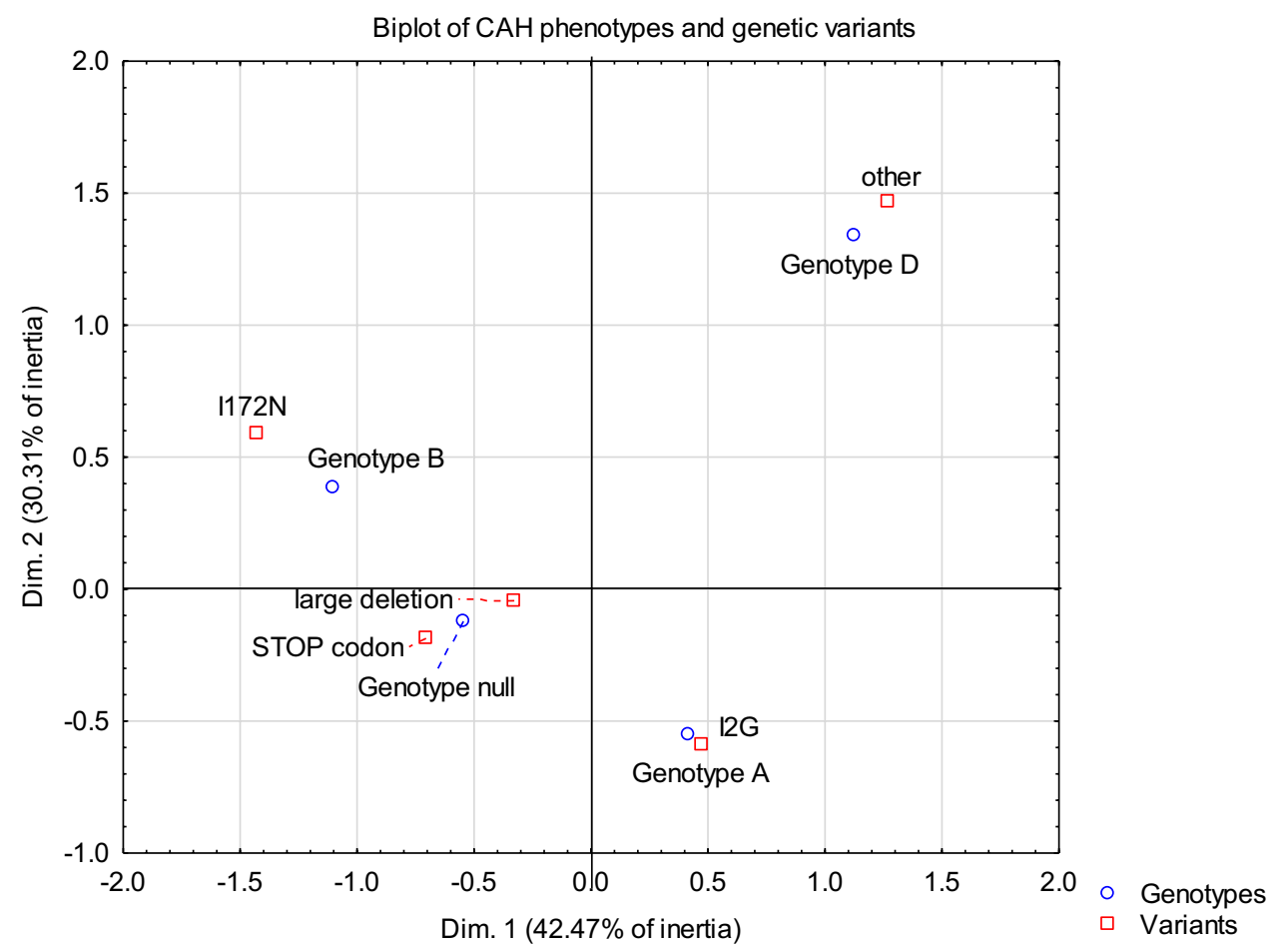


Fig. 2 Visual representation of data profiles - $\mathrm{CAH}$ genotypes and genetic variants
Table 1 Genetic variants among 88 alleles

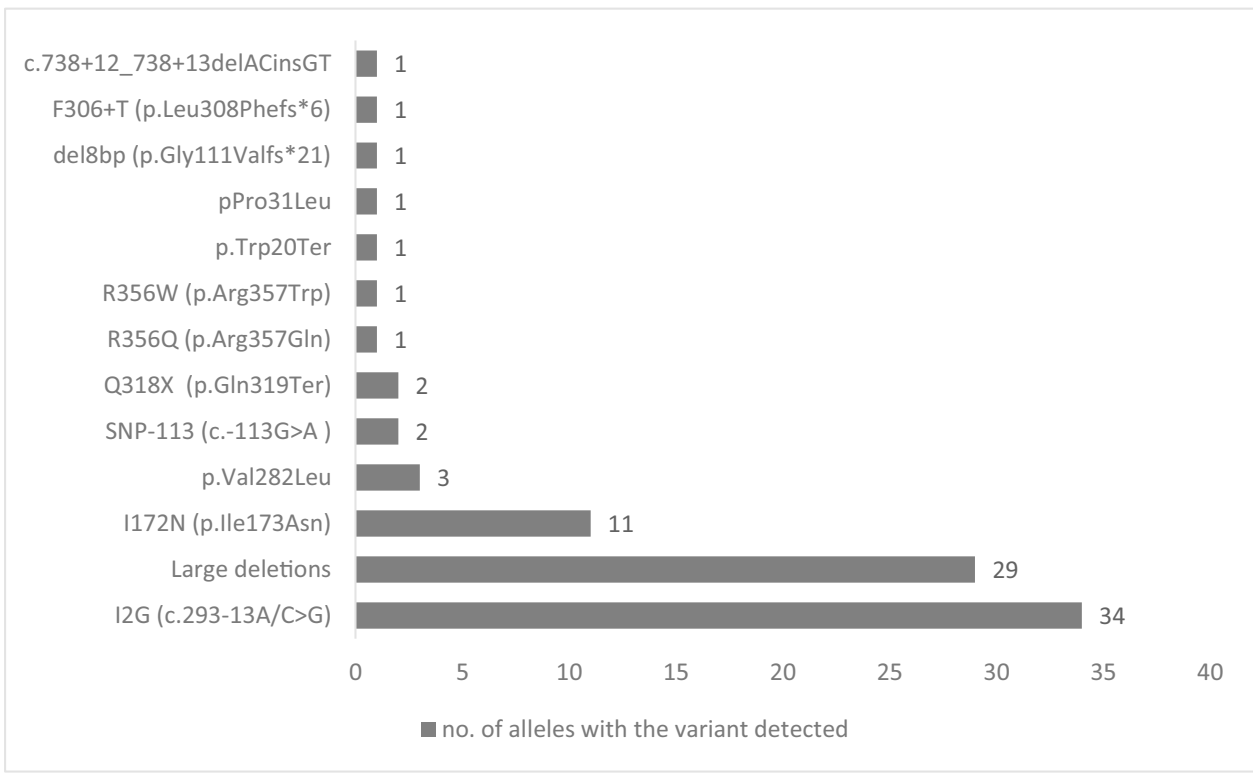

Genetic variants distribution among 88 alleles

\begin{tabular}{llllll}
\hline & Genotype null & Genotype A & Genotype B & Genotype D & $p$ \\
& $n=12$ & $n=42$ & $n=22$ & $n=12$ & \\
del & $9(75.0)$ & $10(23.8)$ & $8(36.4)$ & $2(16.7)$ & $<0.001$ \\
I172N & 0 & 0 & $12(54.5)$ & 0 & $<0.001$ \\
I2G & 0 & $30(71.4)$ & $2(9.1)$ & $2(16.7)$ & $<0.001$ \\
STOP codon & $3(25.0)$ & 0 & 0 & 0 & $<0.001$ \\
other & 0 & $2(4.8)$ & 0 & $8(66.7)$ & $<0.001$ \\
\hline
\end{tabular}

Categorical data were compared with the chi-square test

\section{Genotype-phenotype correlations}

All genotypes were classified into four groups, as follows: null, group A, group B, and group D. Six patients were assigned to group null, 21 patients presented genotype A, and 11 had genotype B, while six patients were classified as genotype D.

Patients assigned to groups null and A were assumed to present a SW phenotype. Patients in genotype group B (with suspected sufficient residual 21-hydroxylase activity) were predicted to have the SV phenotype. Patients in group $\mathrm{C}$ were hypothesized to have the NCCAH clinical manifestation (but they were excluded from the study). Severe genotypes (null and A) demonstrated a good correlation with the expected phenotype, with positive predictive value (PPV) of 100 and $90.5 \%$, respectively, whereas the less severe genotype B demonstrated a lower correlation (with PPV 66.7\%). Nine patients presented a different phenotype from what had been expected (seven in the SW group and two in SV).

There were no differences in anthropometric data among the groups. In our study, patients with genotypes null, A, and B were overweight, with a BMI of $27.2 \pm 8.0,27.3 \pm$ 5.9 , and $28.3 \pm 6.8 \mathrm{~kg} / \mathrm{m} 2$, respectively. Age at menarche was also comparable. Blood glucose values were higher in group $A$, with a trend towards statistical significance ( $P$-value 0.056$)$. The clinical and molecular data according to genotypes are illustrated in Table 2.

\section{Novel variant}

One novel variant was found in one allele in the study group, namely, c.[878G > T] (p.Gly293Val). This variant has not yet been described in the literature. However, another variant at this position, c.878G $>$ A (p.Gly293Asp), has been associated with $\mathrm{CCAH}$ and shown to result in residual enzyme activity of $<1 \%$ [17].

We used bioinformatics tools to predict the effect of the variant detected in our study on protein function. The identified variant, c.[878G $>\mathrm{T}]$, has been predicted to be deleterious by PROVEAN (scored -8.38 at a cutoff of -2.5) [18] and damaging by SIFT (scored 0.000 at a cutoff of 0.05) [19]. Also according to the Bayes classifier applied in 
Table 2 Clinical and molecular data according to genotypes

\begin{tabular}{|c|c|c|c|c|c|}
\hline & $\begin{array}{l}\text { Genotype null } \\
n=6\end{array}$ & $\begin{array}{l}\text { Genotype A } \\
n=21\end{array}$ & $\begin{array}{l}\text { Genotype B } \\
n=11\end{array}$ & $\begin{array}{l}\text { Genotype D } \\
n=6\end{array}$ & $p$ \\
\hline \multirow[t]{2}{*}{ Male sex (N [\%]) } & $2(33.3)$ & $7(33.3)$ & $3(36.4)$ & $1(16.7)$ & 0.861 \\
\hline & \multicolumn{3}{|c|}{ CCAH type (N [\%]): } & & 0.010 \\
\hline SV & $0(0.0)$ & $2(9.5)$ & $4(36.4)$ & $4(66.7)$ & \\
\hline SW & $6(100.0)$ & $19(90.5)$ & $7(63.6)$ & $2(33.3)$ & \\
\hline Age of inclusion in the study (years)(Me [Q1; Q3]) & $20.5(19.0 ; 26.0)$ & $28.0(20.0 ; 31.0)$ & $23.0(20.0 ; 48.0)$ & $24.0(20.0 ; 28.0)$ & 0.756 \\
\hline Menarche (years) (Me [Q1; Q3]) & $13.5(12.5 ; 17.0)$ & $13.0(12.0 ; 14.5)$ & $12.5(11.0 ; 14.0)$ & $12.0(11.0 ; 14.0)$ & 0.582 \\
\hline Height $(\mathrm{cm})(\bar{x} \pm \mathrm{SD})$ & $161.3 \pm 11.7$ & $159.4 \pm 11.9$ & $161.6 \pm 4.9$ & $160.2 \pm 10.2$ & 0.978 \\
\hline BMI $(\mathrm{kg} / \mathrm{m} 2)(\bar{x} \pm \mathrm{SD})$ & $27.2 \pm 8.0$ & $27.3 \pm 5.9$ & $28.3 \pm 6.8$ & $22.0 \pm 3.0$ & 0.187 \\
\hline 17-OHP serum concentration (nmol/L) (Me [Q1; Q3]) & $24.5(6.0 ; 43.9)$ & $28.7(8.8 ; 60.5)$ & $18.8(14.2 ; 60.5)$ & $14.2(4.8 ; 33.0)$ & 0.874 \\
\hline \multirow[t]{2}{*}{ Fasting glucose $(\mathrm{mmol} / \mathrm{l})( \pm \mathrm{SD})$} & $4.5 \pm 0.2$ & $4.8 \pm 0.5$ & $4.4 \pm 0.6$ & $4.4 \pm 0.4$ & 0.056 \\
\hline & \multicolumn{2}{|c|}{ Expected effect(N [\%]): } & & & 0.164 \\
\hline Full blown & $6(100.0)$ & $18(85.7)$ & $11(100.0)$ & $4(66.7)$ & \\
\hline Carrier & $0(0.0)$ & $3(14.3)$ & $0(0.0)$ & $2(33.3)$ & \\
\hline Maximal residual enzyme activity: & & & & & $<0.001$ \\
\hline $0 \%$ & $6(100)$ & $1(4.8)$ & 0 & 0 & \\
\hline$<1 \%$ & 0 & $18(85.7)$ & 0 & 0 & \\
\hline $1 \%$ & 0 & $2(9.5)$ & 0 & 0 & \\
\hline $2-11 \%$ & 0 & 0 & $11(100)$ & 0 & \\
\hline Unknown & 0 & 0 & 0 & $6(100)$ & \\
\hline \multicolumn{6}{|l|}{ Treatment } \\
\hline Hydrocortisone (N (\%]) & $6(100.0)$ & $19(90.5)$ & $10(90.9)$ & $5(83.3)$ & 0.802 \\
\hline Dexamethasone (N [\%]) & $6(100.0)$ & $15(71.4)$ & $7(63.6)$ & $2(33.3)$ & 0.101 \\
\hline Prednisone (N [\%]) & $0(0.0)$ & $7(33.3)$ & $0(0.0)$ & $0(0.0)$ & 0.031 \\
\hline Fludrocortisone (N [\%]) & $6(100.0)$ & $17(81.0)$ & $8(72.7)$ & $3(50.0)$ & 0.213 \\
\hline
\end{tabular}

$C C A H$, classical congenital adrenal hyperplasia; $S V$, simple virilizing; $S W$, salt-wasting; $17-O H P$, 17-hydroxyprogesterone. Continuous data were compared using the Kruskal-Wallis. Categorical data were compared with the chi-square test

MutationTaster, the identified variant has been predicted to be disease-causing [20].

The clinical severity of the new variant could be deduced from the patient's phenotype since he had a severe alteration (deletion of most of the gene) of the other allele.

\section{Discussion}

This study identifies the spectrum and frequencies of CYP21A2 variants as well as genotype-phenotype correlations in a group of 48 adult patients with CCAH due to 21-hydroxylase deficiency treated in the Department of Endocrinology at the University Hospital in Krakow, Poland. To the best of our knowledge, our study is the first published report on the spectrum and frequency of CYP21A2 genetic alterations in the Polish population. As the distribution of CYP21A2 variants differs between individual populations, the results of the study may be a valuable tool in genetic counseling not only in Polish patients with CCAH but also in populations of the entire European area.
The most common genetic variant in the studied group was $\mathrm{I} 2 \mathrm{G}$, followed by whole or partial gene copy deletion. In a study of $155 \mathrm{CAH}$ patients from southern Germany (92 $\mathrm{SW}$ and $52 \mathrm{SV}$ ), I2G was also mentioned as the most common genetic variant [13]. A high frequency of this alteration was also observed by authors from Croatia [21], Turkey [22], India [23], Cuba [24], and China [25, 26]. In previous studies from Latin American countries (Argentina [27], Brazil [28]), and Portugal [29]), p.Val282Leu, which is the most frequent variant in NCCAH, was defined as the most common genetic alteration. Because only CCAH patients were enrolled in the present study, the latter variant accounted for only $3.41 \%$ of cases. It is believed that these differences in genotype frequencies in different countries may result from the heterogeneity/homogeneity of the studied population and different proportions of particular types of CAH in published series. The most common genetic alterations reported in several previous studies are summed up in Table 3.

In our study group, a good correlation between genotype and phenotype was observed in group null (patients with alterations in both alleles resulting in $0 \%$ residual enzyme 
Table 3 Most common genetic alterations reported in several previous studies

\begin{tabular}{|c|c|c|c|c|c|c|c|c|}
\hline \multirow[t]{2}{*}{ Country } & \multirow[t]{2}{*}{ Study (first author) } & \multirow{2}{*}{$\begin{array}{l}\text { Year of } \\
\text { publication }\end{array}$} & \multirow{2}{*}{$\begin{array}{l}\text { Centers included } \\
\text { in the study }\end{array}$} & \multirow{2}{*}{$\begin{array}{l}\text { Total CAH cases } \\
\text { (CCAH and NCAH) }\end{array}$} & \multicolumn{2}{|c|}{$\mathrm{CCAH}$} & \multirow{2}{*}{$\begin{array}{l}\text { Most common } \\
\text { genetic alteration }\end{array}$} & \multirow[t]{2}{*}{ Frequency $(\%)$} \\
\hline & & & & & SW & SV & & \\
\hline $\begin{array}{l}\text { Germany } \\
\text { Austria }\end{array}$ & Riedl S. & 2019 & Multicenter & 538 & 386 & 98 & Del/conversions & 29.6 \\
\hline Germany & Krone N. & 2000 & Multicenter & 155 & 92 & 52 & $\mathrm{I} 2 \mathrm{G}$ & 30.3 \\
\hline Croatia & Dumic KK. & 2017 & Multicenter & 93 & 66 & 23 & $\mathrm{I} 2 \mathrm{G}$ & 35.5 \\
\hline Turkey & Turan I. & 2020 & Single center & 113 & 82 & 24 & $\mathrm{I} 2 \mathrm{G}$ & 38.4 \\
\hline India & Khajuria R. & 2017 & Single center & 55 & 19 & 30 & $\mathrm{I} 2 \mathrm{G}$ & 20.0 \\
\hline China & $\begin{array}{l}\text { Xu C. } \\
\text { Wang R. }\end{array}$ & $\begin{array}{l}2019 \\
2016\end{array}$ & $\begin{array}{l}\text { Single } \\
\text { center } \\
\text { Single center }\end{array}$ & $\begin{array}{l}72 \\
230\end{array}$ & $\begin{array}{l}47 \\
142\end{array}$ & $\begin{array}{l}11 \\
60\end{array}$ & $\begin{array}{l}\mathrm{I} 2 \mathrm{G} \\
\mathrm{I} 2 \mathrm{G}\end{array}$ & $\begin{array}{l}33.0 \\
35.0\end{array}$ \\
\hline Serbia & Milacic I. & 2015 & Multicenter & 61 & 19 & 15 & $\mathrm{I} 2 \mathrm{G}$ & 18.5 \\
\hline Cuba & Espinosa Reyes TM. & 2020 & Single center & 31 & 16 & 12 & $\mathrm{I} 2 \mathrm{G}$ & 38.7 \\
\hline Argentina & Marino R. & 2011 & Multicenter & 454 & 162 & 75 & p.Val282Leu & 26.2 \\
\hline Brazil & De Carvalho DF. & 2016 & Single center & 480 & 158 & 116 & p.Val282Leu & 26.6 \\
\hline Portugal & Santos-Silva R. & 2019 & Multicenter & 212 & 61 & 24 & p.Val282Leu & 41.3 \\
\hline Cyprus & Neocleous V. & 2019 & Multicenter & 120 & 11 & 7 & p.Val282Leu & 60.0 \\
\hline USA & New MI. & 2013 & Multicenter & 1500 & 606 & 187 & p.Val282Leu & 23.9 \\
\hline
\end{tabular}

activity) and group A (0-1\% residual enzyme function). Only in seven patients with SW and in two with SV was there no concordance between genotype and phenotype. Genotype-phenotype correlations measured by PPV were as follows: $100 \%$ in group null, $90.5 \%$ in group A, and $66.7 \%$ in group B. Results of previous studies confirm a good correlation between the genotype and the observed CAH phenotype [26, 28, 30-33]. Previous studies reported $100 \%$ concordance in null, 80-96\% in A, and about $50-87 \%$ in $\mathrm{B}$ genotypes $[13,27,34,35]$. In a huge cohort study by New at al., based on 1507 families with CAH, a genotypephenotype non-concordance was observed in $50 \%$ of cases [36]. A recent German-Austrian study, which enrolled the largest European cohort of $\mathrm{CAH}$ patients from 28 centers (538 CAH cases), has reported a poor correlation in the less severe genotypes B (46\%) and C (58\%) [37].

In four patients of our study, extensive rearrangements were detected, and numerous pathogenic variants were found. These patients have been excluded from further analysis since it was impossible to determine the allelic distributions of these variants without performing an evaluation of the patients' parents, who were unavailable for genetic testing. In the latter group, one novel variant has been identified.

In our study group, there were more female than male patients. This is in agreement with previous data, according to which a substantial proportion of male patients remain undiagnosed [36]. In our study, adult patients were included in whom the diagnosis of CCAH was made years ago when neonatal screening was not available in Poland. This higher proportion of women is typical for countries where neonatal screening has not been routinely used. We believe that this trend may be reversed in future given that neonatal screening for CAH was introduced in Poland in 2016 [38].

In all groups null, A, B, and D, the patients' BMI was > $25 \mathrm{~kg} / \mathrm{m} 2$. The tendency for obesity in CCAH accords with the data reported in previous studies [39, 40]. Fasting blood glucose concentration was higher in group A, with a trend towards statistical significance. One of the largest studies on cardiometabolic complications also demonstrated higher frequencies of obesity and diabetes (mainly type 2) in $\mathrm{CAH}$ patients [41].

One novel variant was found in one allele in the study group, namely, c.[878G $>\mathrm{T}]$ (p.Gly293Val). By means of bioinformatics tools, the identified variant has been predicted to be pathogenic.

The patient had a severe alteration (deletion of most of the gene) on another allele. The clinical severity of the new variant could be deduced from the patient's phenotype; the diagnosis of SW in this patient was established in the neonatal period, when he presented symptoms of adrenal crisis and required glucocorticoid and mineralocorticoid therapy.

However, the small study group being a limitation of this study, the observed non-concordance between genotype and phenotype requires further investigation.

Due to the fact that neonatal screening has been widely introduced in most countries, the number of patients diagnosed with $\mathrm{CCAH}$ is expected to increase in the future. The results of the present study, and particularly the description of the novel variant, may contribute to a better understanding of the disease. Moreover, the presented data can be useful for the prediction of phenotype based on genotype and may be helpful not only in genetic counseling but also in making 
treatment decisions. The practical implication of the data is that special attention must be paid to patients with no or very low 21-hydroxylase activity determined by genotype, in whom in cases of insufficient doses of corticoids or concomitant acute diseases adrenal crisis may occur.

\section{Conclusions}

The majority of cases in our study were characterized by a strong genotype-phenotype correlation. Variant frequencies of affected alleles were similar to those of data previously reported for other countries of the region. The most common genetic variant in the study cohort was $\mathrm{I} 2 \mathrm{G}$, followed by large deletions and I172N. One novel variant, c.[878G $>$ T] (p.Gly293 Val), has been identified and characterized by means of bioinformatics tools.

Funding This study was supported by funds from the subsidies of the Ministry of Science and Higher Education: No. K/ZDS/004513.

\section{Declarations}

Ethics approval The study was approved by the Ethics Committee of the Jagiellonian University Medical College, Krakow, Poland: KBET/225/B/2013.

Consent to participate Informed consent was obtained from all individual participants included in the study.

Conflict of interest The authors declare no competing interests.

Open Access This article is licensed under a Creative Commons Attribution 4.0 International License, which permits use, sharing, adaptation, distribution and reproduction in any medium or format, as long as you give appropriate credit to the original author(s) and the source, provide a link to the Creative Commons licence, and indicate if changes were made. The images or other third party material in this article are included in the article's Creative Commons licence, unless indicated otherwise in a credit line to the material. If material is not included in the article's Creative Commons licence and your intended use is not permitted by statutory regulation or exceeds the permitted use, you will need to obtain permission directly from the copyright holder. To view a copy of this licence, visit http://creativecommons.org/licenses/by/4.0/.

\section{References}

1. Merke DP, Auchus RJ (2020) Congenital adrenal hyperplasia due to 21-hydroxylase deficiency. N Engl J Med 383:1248-1261. https://doi.org/10.1056/NEJMra1909786

2. Speiser PW, Arlt W, Auchus RJ, Baskin LS, Conway GS, Merke DP, Meyer-Bahlburg HFL, Miller WL, Murad MH, Oberfield SE, White PC (2018) Congenital adrenal hyperplasia due to steroid 21-hydroxylase deficiency: an endocrine society clinical practice guideline. J Clin Endocrinol Metab 103:4043-4088. https://doi. org/10.1210/jc.2018-01865

3. El-Maouche D, Arlt W, Merke DP (2017) Congenital adrenal hyperplasia. Lancet 390(10108):2194-2210. https://doi.org/10. 1016/S0140-6736(17)31431-9

4. Krone N, Rose IT, Willis DS, Hodson J, Wild SH, Doherty EJ, Hahner S, Parajes S, Stimson RH, Han TS, Carroll PV, Conway GS, Walker BR, MacDonald F, Ross RJ, Arlt W (2013) Genotype-phenotype correlation in 153 adult patients with congenital adrenal hyperplasia due to 21-hydroxylase deficiency: analysis of the United Kingdom congenital adrenal hyperplasia adult study executive (CaHASE) cohort. J Clin Endocrinol Metab 98:346354. https://doi.org/10.1210/jc.2012-3343

5. Trakakis E, Basios G, Trompoukis P, Labos G, Grammatikakis I, Kassanos D (2010) An update to 21-hydroxylase deficient congenital adrenal hyperplasia. Gynecol Endocrinol 26:63-71. https:// doi.org/10.3109/09513590903015494

6. Pang S, Murphey W, Levine LS, Spence DA, Leon A, LaFranchi S, Surve AS, New MI (1982) A pilot newborn screening for congenital adrenal hyperplasia in Alaska. J Clin Endocrinol Metab 55:413-420. https://doi.org/10.1210/jcem-55-3-413

7. Speiser PW, White PC (2003) Congenital adrenal hyperplasia. N Engl J Med 349:776-788. https://doi.org/10.1056/NEJMra021561

8. Speiser PW, Chawla R, Chen M, Diaz-Thomas A, Finlayson C, Rutter MM, Sandberg DE, Shimy K, Talib R, Cerise J, Vilain E, Délot EC (2020) Newborn screening protocols and positive predictive value for congenital adrenal hyperplasia vary across the United States. Int J Neonatal Screen 6:37. https://doi.org/10. 3390/ijns6020037

9. White PC, New MI, Dupont B (1986) Structure of human steroid 21-hydroxylase genes. Proc Natl Acad Sci U S A 83:5111-5115. https://doi.org/10.1073/pnas.83.14.5111

10. Parsa AA, New MI (2017) Steroid 21-hydroxylase deficiency in congenital adrenal hyperplasia. J Steroid Biochem Mol Biol 165:2-11. https://doi.org/10.1016/j.jsbmb.2016.06.015

11. Concolino P, Costella A (2018) Congenital adrenal hyperplasia ( $\mathrm{CAH}$ ) due to 21-hydroxylase deficiency: a comprehensive focus on 233 pathogenic variants of CYP21A2 gene. Mol Diagn Ther 22:261-280. https://doi.org/10.1007/s40291-018-0319-y

12. Simonetti L, Bruque C, Fernández C, Benavides-Mori B, Delea M, Kolomenski JE, Espeche LD, Buzzalino ND, Nadra AD, Dain L (2018) CYP21A2 mutation update: comprehensive analysis of databases and published genetic variants. Hum Mutat 39:5-22. https://doi.org/10.1002/humu.23351

13. Krone N, Braun A, Roscher AA, Knorr D, Schwarz HP (2000) Predicting phenotype in steroid 21-hydroxylase deficiency. Comprehensive genotyping in 155 unrelated, well defined patients from southern Germany. Clin Endocrinol Metab 85:1059-1065. https://doi.org/10.1210/jcem.85.3.6441

14. Xu Z, Chen W, Merke DP, McDonnell NB (2013) Comprehensive mutation analysis of the CYP21A2 gene: an efficient multistep approach to the molecular diagnosis of congenital adrenal hyperplasia. J Mol Diagn 15:745-753. https://doi.org/10.1016/j.jmoldx. 2013.06.001

15. Wedell A, Thilén A, Ritzén EM, Ritzén EM, Stengler B, Luthman H (1994) Mutational spectrum of the steroid 21-hydroxylase gene in Sweden: implications for genetic diagnosis and association with disease manifestation. J Clin Endocrinol Metab 78:1145-1152. https://doi.org/10.1210/jcem.78.5.8175971

16. Speiser PW, Dupont J, Zhu D, Serrat J, Buegeleisen M, TusieLuna MT, Lesser M, New MI, White PC (1992) Disease expression and molecular genotype in congenital adrenal hyperplasia due to 21-hydroxylase deficiency. J Clin Invest 90:584-595. https://doi.org/10.1172/JCI115897 
17. Tardy V, Menassa R, Sulmont V, Lienhardt-Roussie A, Lecointre C, Brauner R, David M, Morel Y (2010) Phenotype-genotype correlations of 13 rare CYP21A2 mutations detected in 46 patients affected with 21-hydroxylase deficiency and in one carrier. J Clin Endocrinol Metab 95:1288-1300. https://doi.org/10.1210/jc. 2009-1202

18. Choi Y, Sims GE, Murphy S, Miller JR, Chan AP (2012) Predicting the functional effect of amino acid substitutions and indels. PLoS One 7(10):e46688. https://doi.org/10.1371/journal.pone. 0046688

19. Kumar P, Henikoff S, Ng PC (2009) Predicting the effects of coding non-synonymous variants on protein function using the SIFT algorithm. Nat Protoc 4:1073-1082. https://doi.org/10.1038/nprot. 2009.86

20. Schwarz JM, Cooper DN, Schuelke M, Seelow D (2014) Mutationtaster2: mutation prediction for the deep-sequencing age. Nat Methods 11:361-362. https://doi.org/10.1038/nmeth.2890

21. Dumic KK, Grubic Z, Yuen T, Wilson RC, Kusec V, Barisic I, Stingl K, Sansovic I, Skrabic V, Dumic M, New MI (2017) Molecular genetic analysis in 93 patients and 193 family members with classical congenital adrenal hyperplasia due to 21-hydroxylase deficiency in Croatia. J Steroid Biochem Mol Biol 165:51-56. https://doi.org/10.1016/j.jsbmb.2016.03.035

22. Turan I, Tastan M, Boga DD, Gurbuz F, Kotan LD, Tuli A, Yüksel B (2020) 21-hydroxylase deficiency: mutational spectrum and genotype - phenotype relations analyses by next-generation sequencing and multiplex ligation- dependent probe amplification. Eur J Med Genet 63:103782. https://doi.org/10.1016/j.ejmg.2019. 103782

23. Khajuria R, Walia R, Bhansali A, Prasad R (2017) The spectrum of CYP21A2 mutations in congenital adrenal hyperplasia in an Indian cohort. Clin Chim Acta 464:189-194. https://doi.org/10. 1016/j.cca.2016.11.037

24. Espinosa Reyes TM, Collazo Mesa T, Lantigua Cruz PA, Agramonte Machado A, Domínguez Alonso E, Falhammar H (2020) Molecular diagnosis of patients with congenital adrenal hyperplasia due to 21-hydroxylase deficiency. BMC Endocr Disord 20:1-8. https://doi.org/10.1186/s12902-020-00643-Z

25. Xu C, Jia W, Cheng X, Ying H, Chen J, Xu J, Guan Q, Zhou X, Zheng D, Li G, Zhao J (2019) Genotype - phenotype correlation study and mutational and hormonal analysis in a Chinese cohort with 21-hydroxylase deficiency. Mol Genet Genomic Med 7:e671. https://doi.org/10.1002/mgg3.671

26. Wang R, Yu Y, Ye J, Han L, Qiu W, Zhang H, Liang L, Gong Z, Wang L, Gu X (2016) 21-hydroxylase deficiency-induced congenital adrenal hyperplasia in 230 Chinese patients: genotypephenotype correlation and identification of nine novel mutations. Steroids 108:47-55. https://doi.org/10.1016/j.steroids.2016.01. 007

27. Marino R, Ramirez P, Galeano J, Perez Garrido N, Rocco C, Ciaccio M, Warman DM, Guercio G, Chaler E, Maceiras M, Bergadá I, Gryngarten M, Balbi V, Pardes E, Rivarola MA, Belgorosky A (2011) Steroid 21-hydroxylase gene mutational spectrum in 454 Argentinean patients : genotype - phenotype correlation in a large cohort of patients with congenital adrenal hyperplasia. Clin Endocrinol 75:427-435. https://doi.org/10.1111/j.1365-2265. 2011.04123.x

28. de Carvalho DF, Miranda MC, Gomes LG, Madureira G, Marcondes JA, Billerbeck AE, Rodrigues AS, Presti PF, Kuperman H, Damiani D, Mendonca BB, Bachega TA (2016) Molecular CYP21A2 diagnosis in 480 Brazilian patients with congenital adrenal hyperplasia before newborn screening introduction. Eur J Endocrinol 175:107-116. https://doi.org/10.1530/EJE-16-0171
29. Santos-Silva R, Cardoso R, Lopes L, Fonseca M, Espada F, Sampaio L, Brandão C, Antunes A, Bragança G, Coelho R, Bernardo T, Vieira P, Morais R, Leite AL, Ribeiro L, Carvalho B, Grangeia A, Oliveira R, Oliveira MJ et al (2019) CYP21A2 gene pathogenic variants: a multicenter study on genotype - phenotype correlation from a Portuguese pediatric cohort. Horm Res Paediatr 91:33-45. https://doi.org/10.1159/000497485

30. Narasimhan ML, Khattab A (2019) Genetics of congenital adrenal hyperplasia and genotype-phenotype correlation. Fertil Steril 111:24-29. https://doi.org/10.1016/j.fertnstert.2018.11.007

31. Milacic I, Barac M, Milenkovic T, Ugrin M, Klaassen K, Skakic A, Jesic M, Joksic I, Mitrovic K, Todorovic S, Vujovic S, Pavlovic S, Stojiljkovic M (2015) Molecular genetic study of congenital adrenal hyperplasia in Serbia: novel p.Leu129Pro and p.Ser165Pro CYP21A2 gene mutations. J Endocrinol Investig 38:1199-1210. https://doi.org/10.1007/s40618-015-0366-8

32. Zhang B, Lu L, Lu Z (2017) Molecular diagnosis of Chinese patients with 21-hydroxylase deficiency and analysis of genotype-phenotype correlations. J Int Med Res 45:481-492. https:// doi.org/10.1177/0300060516685204

33. Neocleous V, Fanis P, Toumba M, Stylianou C, Picolos M, Andreou E, Kyriakou A, Iasonides M, Nicolaou S, Kyriakides TC, Tanteles GA, Skordis N, Phylactou LA (2019) The spectrum of genetic defects in congenital adrenal hyperplasia in the population of Cyprus: a retrospective analysis. Horm Metab Res 51:586-594. https://doi.org/10.1055/a-0957-3297

34. Dundar A, Bayramov R, Onal MG, Akkus M, Dogan ME, Kenanoglu S, Cerrah Gunes M, Kazimli U, Ozbek MN, Ercan O, Yildirim R, Celmeli G, Parlak M, Dundar I, Hatipoglu N, Unluhizarci K, Akalin H, Ozkul Y, Saatci C, Dundar M (2019) The molecular basis and genotype-phenotype correlations of congenital adrenal hyperplasia (CAH) in Anatolian population. Mol Biol Rep 46:3677-3690. https://doi.org/10.1007/s11033-019-04809-4

35. Finkielstain GP, Chen W, Mehta SP, Fujimura FK, Hanna RM, Van Ryzin C, McDonnell NB, Merke DP (2011) Comprehensive genetic analysis of 182 unrelated families with congenital adrenal hyperplasia due to 21-hydroxylase deficiency. J Clin Endocrinol Metab 96:E161-E172. https://doi.org/10.1210/jc.2010-0319

36. New MI, Abraham M, Gonzalez B, Dumic M, Razzaghy-Azar M, Chitayat D, Sun L, Zaidi M, Wilson RC, Yuen T (2013) Genotypephenotype correlation in 1,507 families with congenital adrenal hyperplasia owing to 21-hydroxylase deficiency. Proc Natl Acad Sci U S A 110:2611-2516. https://doi.org/10.1073/pnas.13000 57110 Epub 2013 Jan 28

37. Riedl S, Röhl FW, Bonfig W, Brämswig J, Richter-Unruh A, Fricke-Otto S, Bettendorf M, Riepe F, Kriegshäuser G, Schönau E, Even G, Hauffa B, Dörr HG, Holl RW, Mohnike K, AQUAPE CAH Study Group (2019) Genotype/phenotype correlations in 538 congenital adrenal hyperplasia patients from Germany and Austria: discordances in milder genotypes and in screened versus prescreening patients. Endocr Connect 8:86-94. https://doi.org/ 10.1530/EC-18-0281

38. Ginalska-Malinowska M (2018) Classic congenital adrenal hyperplasia due to 21-hydroxylase deficiency - the next disease included in the neonatal screening program in Poland. Dev Period Med 22:197-200

39. Gomes LG, Mendonca BB, Bachega TASS (2020) Long-term cardio-metabolic outcomes in patients with classical congenital adrenal hyperplasia: is the risk real? Curr Opin Endocrinol Diabetes Obes 27:155-161. https://doi.org/10.1097/MED.0000000000 000545

40. Paizoni L, Auer MK, Schmidt H, Hübner A, Bidlingmaier M, Reisch N (2020) Effect of androgen excess and glucocorticoid exposure on metabolic risk profiles in patients with congenital 
adrenal hyperplasia due to 21-hydroxylase deficiency. J Steroid Biochem Mol Biol 197:105540. https://doi.org/10.1016/j.jsbmb. 2019.105540

41. Falhammar H, Frisén L, Hirschberg AL, Norrby C, Almqvist C, Nordenskjöld A, Nordenström A (2015) Increased cardiovascular and metabolic morbidity in patients with 21-hydroxylase deficiency: a Swedish Population-Based National Cohort Study. J Clin Endocrinol Metab 100:3520-3528. https://doi.org/10.1210/ JC.2015-2093

Publisher's note Springer Nature remains neutral with regard to jurisdictional claims in published maps and institutional affiliations. 